
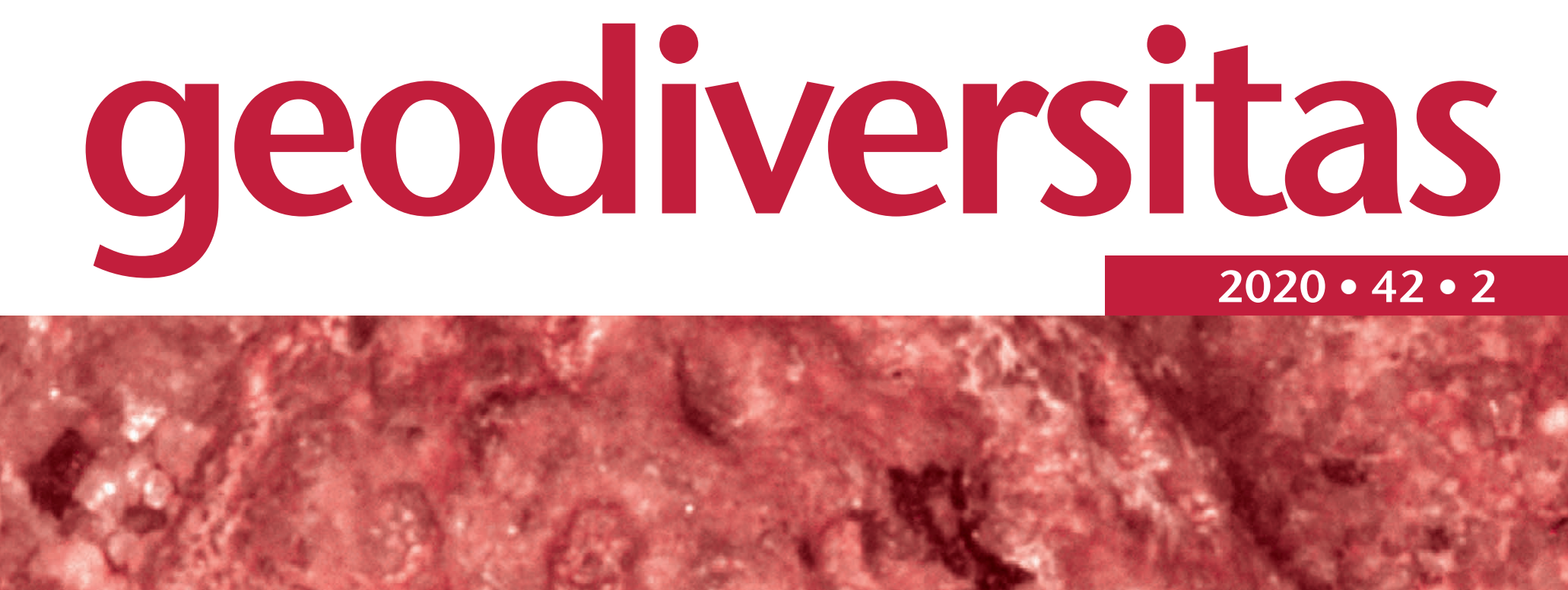

* Icacinaceae fossil fruits from three sites of the Paris Basin (early Eocente, France): local diversity and global bjogeographic implications

Cédric DEL RIO \& Dario DE FRANCESCHI

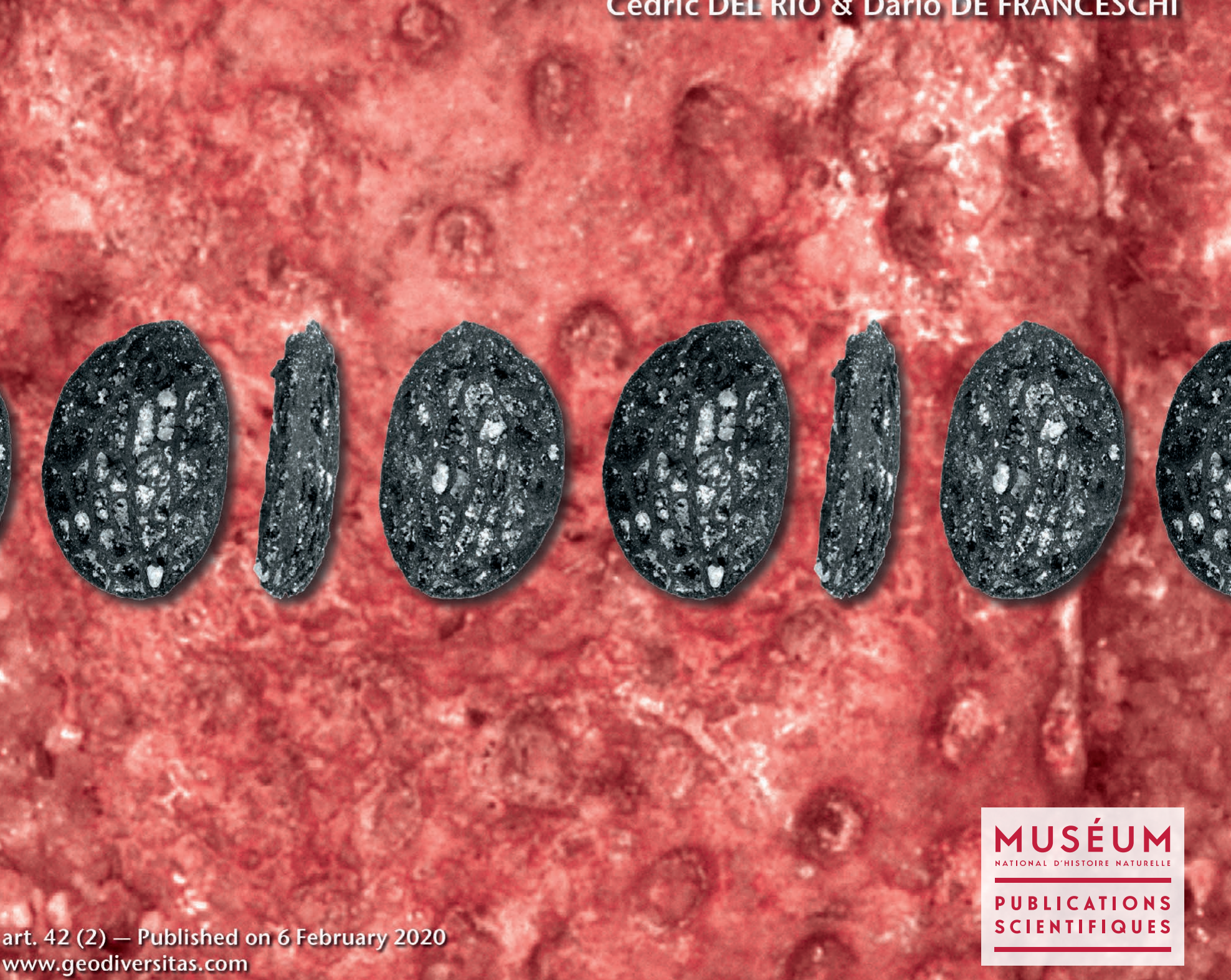


DiRECTEUR DE LA PUblication: Bruno David,

Président du Muséum national d'Histoire naturelle

RÉdACTEUR EN CHEF / EDITOR-IN-CHIEF: Didier Merle

ASSISTANTS DE RÉDACTION / ASSISTANT EDITORS: Emmanuel Côtez (geodiv@mnhn.fr)

Mise EN PAGE / PAGE LAYOUT: Emmanuel Côtez

COMITÉ SCIENTIFIQUE / SCIENTIFIC BOARD:

Christine Argot (MNHN, Paris)

Beatrix Azanza (Museo Nacional de Ciencias Naturales, Madrid)

Raymond L. Bernor (Howard University, Washington DC)

Alain Blieck (chercheur CNRS retraité, Haubourdin)

Henning Blom (Uppsala University)

Jean Broutin (UPMC, Paris)

Gaël Clément (MNHN, Paris)

Ted Daeschler (Academy of Natural Sciences, Philadelphie)

Bruno David (MNHN, Paris)

Gregory D. Edgecombe (The Natural History Museum, Londres)

Ursula Göhlich (Natural History Museum Vienna)

Jin Meng (American Museum of Natural History, New York)

Brigitte Meyer-Berthaud (CIRAD, Montpellier)

Zhu Min (Chinese Academy of Sciences, Pékin)

Isabelle Rouget (UPMC, Paris)

Sevket Sen (MNHN, Paris)

Stanislav Štamberg (Museum of Eastern Bohemia, Hradec Králové)

Paul Taylor (The Natural History Museum, Londres)

COUVERTURE / COVER:

Made from the Figures of the article.

Geodiversitas est indexé dans / Geodiversitas is indexed in:

- Science Citation Index Expanded (SciSearch $\left.{ }^{\circledR}\right)$

- ISI Alerting Services ${ }^{\circledR}$

- Current Contents ${ }^{\circledR} /$ Physical, Chemical, and Earth Sciences ${ }^{\circledR}$

- Scopus ${ }^{\circledR}$

Geodiversitas est distribué en version électronique par / Geodiversitas is distributed electronically by:

- BioOne ${ }^{\circledR}$ (http://www.bioone.org)

Les articles ainsi que les nouveautés nomenclaturales publiés dans Geodiversitas sont référencés par / Articles and nomenclatural novelties published in Geodiversitas are referenced by:

- ZooBank ${ }^{\circledR}$ (http://zoobank.org)

Geodiversitas est une revue en flux continu publiée par les Publications scientifiques du Muséum, Paris Geodiversitas is a fast track journal published by the Museum Science Press, Paris

Les Publications scientifiques du Muséum publient aussi / The Museum Science Press also publish:

Adansonia, Zoosystema, Anthropozoologica, European Journal of Taxonomy, Naturae, Cryptogamie sous-sections Algologie, Bryologie, Mycologie.

Diffusion - Publications scientifiques Muséum national d'Histoire naturelle

CP $41-57$ rue Cuvier F-75231 Paris cedex 05 (France)

Tél. : 33 (0)1407948 05 / Fax: 33 (0)14079 3840

diff.pub@mnhn.fr / http://sciencepress.mnhn.fr

(C) Publications scientifiques du Muséum national d'Histoire naturelle, Paris, 2020

ISSN (imprimé / print): 1280-9659/ ISSN (électronique / electronic): 1638-9395 


\title{
Icacinaceae fossil fruits from three sites of the Paris Basin (early Eocene, France): local diversity and global biogeographic implications
}

\author{
Cédric DEL RIO \\ CR2P (CNRS, MNHN, Sorbonne Université), \\ Département Origines et Évolution, Muséum national d'Histoire naturelle, \\ case postale 38, 57 rue Cuvier, F-75231 Paris cedex 05 (France) \\ and ISYEB (CNRS, MNHN, EPHE, Sorbonne Université), \\ Institut Systématique Évolution Biodiversité, Muséum national d'Histoire naturelle, \\ case postale 39, 57 rue Cuvier, F-75231 Paris cedex 05 (France) \\ and CAS Key Laboratory of Tropical Forest Ecology, Xishuangbanna Tropical Botanical Garden, \\ Chinese Academy of Sciences, Mengla, Yunnan 666303 (China)
}

Dario De FRANCESCHI

CR2P (CNRS, MNHN, Sorbonne Université), Département Origines et Évolution, Muséum national d'Histoire naturelle, case postale 38, 57 rue Cuvier, F-75231 Paris cedex 05 (France)

Submitted on 11 March 2019 | accepted on 25 June 2019 | published on 6 February 2020

urn:Isid:zoobank.org:pub:78CE477A-B911-429B-8CA4-267640206CAF

Del Rio C. \& De Franceschi D. 2020. - Icacinaceae fossil fruits from three sites of the Paris Basin (early Eocene, France): local diversity and global biogeographic implications. Geodiversitas 42 (2): 17-28. https://doi.org/10.5252/ geodiversitas2020v42a2. http://geodiversitas.com/42/2

\section{ABSTRACT}

The Icacinaceae family have an important fossil record, mainly in the Paleogene of North America and Europe. The importance of this family in the Paleogene of the Paris Basin has been investigated recently based on two assemblages, Le Quesnoy (Houdancourt) and Rivecourt (Oise), and here we treat the Icacinaceae from three additional early Eocene sites. The Passy site reveals the presence of a new species, Iodes passiciensis Del Rio \& De Franceschi, sp. nov., unique in having 25-29 areoles with no freely ending ridgelets, small pores, and rounded ridges. Two other species described previously

KEY WORDS

Eocene,

France,

Paris Basin,

biogeography, new species. from the Paleocene of Rivecourt were also recorded. The Grès de Belleu site also includes the first occurrence of a Palaeophytocrene Reid \& Chandler in the Paris Basin and an Iodes Blume specimen without precise assignment. Lastly, in the Prémontré site only one endocarp locule cast belonging to Icacinicaryites Pigg, Manchester \& DeVore was recorded and described. Using data from all five sites, the diversity of Icacinaceae in the Paris Basin is discussed and biogeographic scenarios are developed.

\section{RÉSUMÉ}

Fruits fossiles d'Icacinaceae provenant de trois sites du Bassin Parisien (début Éocène, France): diversité locale et implications biogéographiques.

La famille des Icacinaceae présente un important registre fossile, principalement durant le Paléogène en Amérique du Nord et en Europe. L’importance de cette famille au niveau du Paléogène du Bassin de Paris a été mise en évidence récemment pour deux sites, Le Quesnoy (Houdancourt) et Rivecourt (Oise). Trois autres sites, datés du début de l'Éocène, sont étudiés ici. Le site de Passy révèle la présence d'une nouvelle espèce, Iodes passiciensis Del Rio \& De Franceschi, sp. nov. qui possède les caractères uniques suivants: 25-29 alvéoles sans crêtes internes libres, de petites protubérances 


\section{MOTS CLÉS}

Éocène,

France,

Bassin de Paris,

biogéographie,

espèce nouvelle. en forme de pores et des crêtes arrondis. Deux autres espèces, déjà décrites pour le site paléocène de Rivecourt, ont également été enregistrées. Le site des Grès de Belleu contient la première occurrence pour le Bassin Parisien de Palaeophytocrene Reid \& Chandler ainsi qu'un Iodes Blume sans attribution spécifique. Enfin, le site de Prémontré montre seulement un moulage interne attribué à Icacinicaryites Pigg, Manchester \& DeVore. En utilisant toutes les données provenant des cinq sites, la diversité des Icacinaceae au niveau du Bassin Parisien est discutée et des évaluations biogéographiques développées.

\section{INTRODUCTION}

Icacinaceae Miers is a group of trees, shrubs, and climbers with a pantropical distribution. The family contains 23 genera and c. 160 species in its current circumscription (Stull et al. 2015). In addition, the family has an important fossil record, mainly from the Paleogene of North America (Scott 1954; Manchester 1994; Pigg et al. 2008; Rankin et al. 2008; Stull et al. 2011, 2012; Allen et al. 2015) and in Europe (Reid \& Chandler 1933; Fairon-Demaret \& Smith 2002; Collinson et al. 2012). The fossil record is best known from endocarp remains, which are the most taxonomically informative organ for this family (Stull et al. 2016).

Within the Paris Basin (France), some sites through the Paleogene give a view of the ancient flora via fruit, seed, pollen and flower remains. Two major sites have been partially studied, Petit Patis (Rivecourt) from the Thanetian, Paleocene (Smith et al. 2014; Del Rio et al. 2019a) and Le Quesnoy (Houdancourt) site from the Ypresian, Eocene (Nel et al. 1999; De Franceschi et al. 2000; De Franceschi \& De Ploëg 2003; Jacques \& De Franceschi 2005; Del Rio et al. 2017, 2019b) mainly for Icacinaceae and Menispermaceae. Indeed, these two sites show a great diversity of Icacinaceae species: the site of Rivecourt revealed five new Iodes Blume species and Le Quesnoy contains two new Iodes species and a flower in amber attributed to the Icacinaceae family (close to the Clade IV sensu Stull et al. 2015; Del Rio et al. 2017).

A preliminary study showed that Icacinaceae were also present in three other Paris Basin sites: Passy (MP8-9), Grès de Belleu (MP10) and Prémontré (MP10). These remains, younger than those of Le Quesnoy, could bring new light on the diversity of the Icacinaceae family during the Ypresian period. Therefore, the aim of this study is to describe the Icacinaceae remains from the three localities, to discuss the diversity of the Icacinaceae in the Paris Basin, and finally to propose local and global biogeographic hypothesis.

\section{MATERIAL AND METHOD}

\section{GEOLOGICAL SETTINGS \& MATERIAL}

The geography of all sites with Icacinaceae remains is shown in the Fig. 1. Among these sites, two were already studied for this family (Del Rio et al. 2017, 2019a, b). In this paper, we explore the Icacinaceae diversity of the three other sites: Passy, Belleu and Prémontré.

The Passy outcrop consists in a sandy layer of three to four meters called "sables d'Auteuil" resting on the "argiles plas- tiques" of the Sparnacian (early Ypresian) and covered by the "fausses glaises" (Ypresian). Passy is now part of the western side of the city of Paris, close to the Eiffel tower. In that area were found in the Ypresian "argiles plastiques" the so-called Paris amber and the first record of Aulacoxylon sparnacense Combes (Combes 1907; see De Franceschi \& De Ploëg 2003), as well as other fossils like Cyrena cuneiformis (Fer.), Melania inquinata Defr., Melanopsis Férussac, 1807 which helped to date the deposits and some conifer pyritized wood (Soyer 1953). The "sables d'Auteuil" are considered to be middle Ypresian (Soyer 1953). The sandy layer was excavated during underground work for a building in 1999 and some sand bags were collected on the site. The sediment was sieved and the remains sorted under a binocular microscope. The five lignitic Icacinaceae fossil endocarps were discovered in that sediment and kept in the Muséum national d'Histoire naturelle, Paris, palaeontological collection (MNHN.F).

Two fossils were collected from the Grès de Belleu (Belleu sandstone) site during the $19^{\text {th }}$ century. The sediment in this site is composed of "grain, assez grossier" (grain, quite coarse) (Watelet 1866) with quartz dominant (Koeniger 1982). The Grès de Belleu was dated by Watelet (1866) as Suessonien (Ypresian) and now attributed to the Late Cuisian (Pomerol et al. 1984). This site has been studied mainly for the leaf imprints by Watelet (Watelet 1866) and revised by Fritel (Fritel 1908, 1924). An update of the flora diversity has been made (Furon $\&$ Soyer 1947) and they kept $c$. forty species. A few number fruits have been found and described (Watelet 1866). They are mainly Fabaceae pods. Among numerous leaves and fruits, two fruits assigned to Icacinaceae were collected and kept in the MNHN collection (MNHN.F.8100 and MNHN.F.8061).

The lower Eocene locality of Prémontré was discovered and described by Dégremont (Dégremont et al. 1985), "à l'occasion des travaux exécutés dans l'enceinte de l'Hôpital psychiatrique de Prémontré" (during the work done on the premises of the Prémontré psychiatric Hospital) and dated from the Cuisian. The fossils were collected in a layer of 4-5 m thick composed of ochreaceous weak sandstone with reddish bands due to oxidation. The Prémontré (Aisne, France) outcrop provided diverse reptilian (Augé et al. 1997; Augé \& Smith 2002; Augé 2003), mammalian (Godinot et al. 1992; Sudre \& Erfurt 1996; Escarguel 1999; Smith 2001) and Chondrichtyes fossils (Cappetta 1992; Adnet \& Cappetta 2008), but also a diverse paleoflora with fruit and seed remains (Blanc-Louvel 1985a, b). Among them, a locule cast was identified as part of the Icacinaceae family and described here. The collection is kept in the MNHN. 


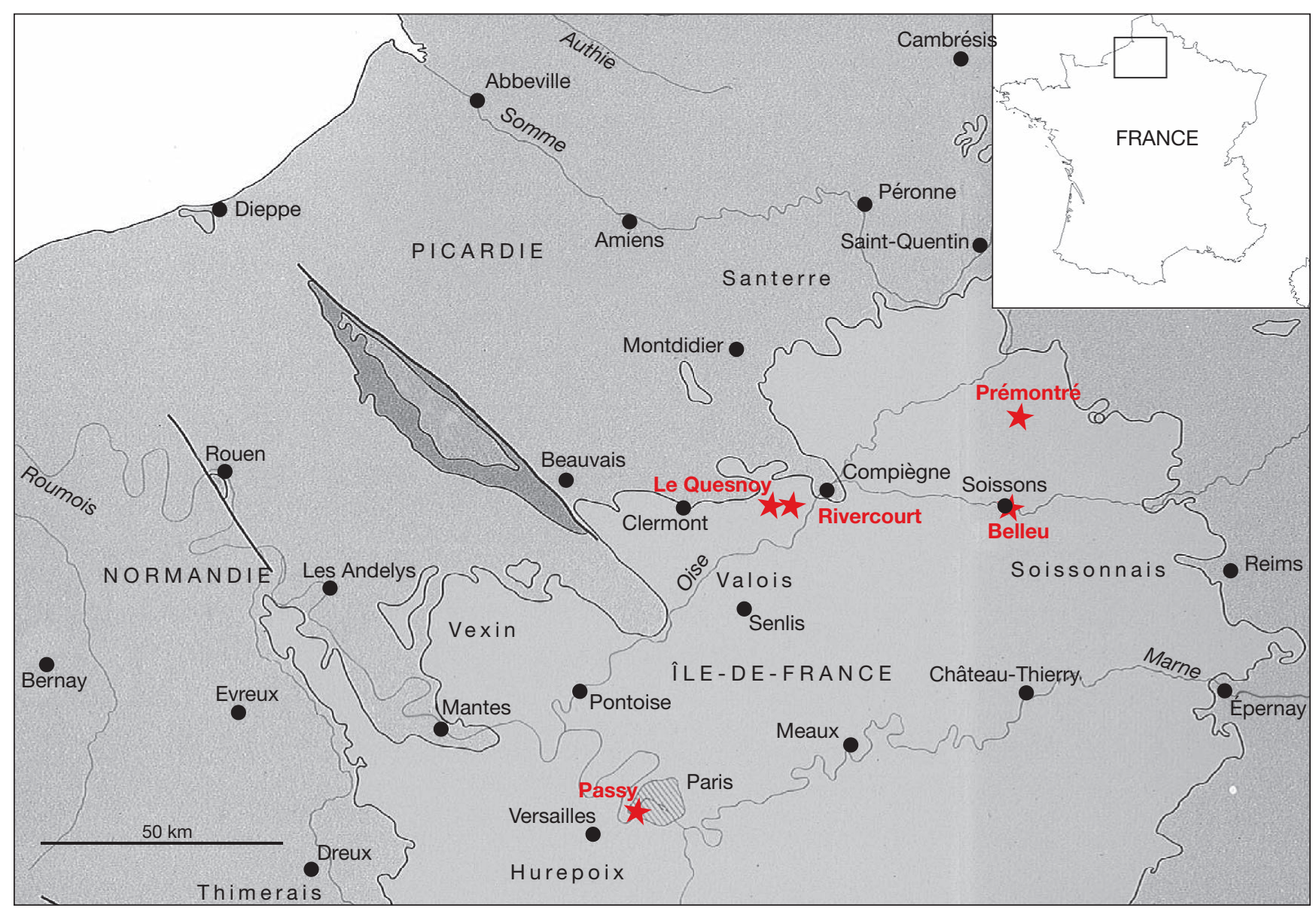

FIG. 1. - Geological map showing the locations of the five sites with Icacinaceae remains in the Paris Basin. Light Grey, Cenozoic; Grey, Upper Cretaceous; Dark grey, Lower Cretaceous. Modified from "Synthèse géologique du Bassin de Paris" (Mégnien 1980).

\section{METHOD OF FOSSIL OBSERVATION}

All specimens were studied with the help of a binocular microscope (Wild M3Z) and imaged with a Leica DFC 420 camera. Measurements were taken using the ImageJ Software (Rasband 2016).

Samples from Passy were coated with gold-palladium for examination by Scanning Electron Microscopy (SEM), using a Jeol JCM6000 instrument, facilitating observation of anatomical features, especially the endocarp wall layers and papillae. Images of the pores of Iodes passiciensis, sp. nov. (Fig. 2F) were captured using a digital microscope Hirox RH2000.

\section{SYSTEMATICS}

\section{PASSY SITE}

All endocarps known from this site are bilateral, asymmetrical at the apex, with a reticulation pattern on the surface and a strong keel, which is characteristic of the Icacinaceae family. In addition, all species have a vascular bundle inside the endocarp wall and some of them show papillae on the surface of the locule. These characters allow us to consider these specimens as belonging to the genus Iodes. However, some differences lead us to describe a new species and record two new occurrences.
Family ICACINACEAE Miers Genus Iodes Blume

\section{Iodes passiciensis}

Del Rio \& De Franceschi, sp. nov.

(Fig. 2A-I)

Endocarp bilaterally symmetrical, unilocular, elliptical, lenticular in transverse section; outer surface of the endocarp with a reticulate pattern of rounded and thin ridges with a channel on the median apical part, enclosing 25-29 polygonal areoles per face, with few or no free-ending ridgelets; a keel surrounds the fruit in the plane of symmetry with the thicker side containing a vascular bundle embedded in the endocarp wall. Endocarp possesses a small pair of pores. Inner endocarp surface densely covered with regularly spaced and sessile rounded papillae. Endocarp length $c .7 \mathrm{~mm}$, width $c .4 .4 \mathrm{~mm}$.

\section{HOLOTYPE. - MNHN.F.44736.}

\section{PARATYPE. - MNHN.F.44739.}

ETyMology. - From the latin name of Passy (Passicum) where the fossil taxon was recovered.
StratigrapHy. - Early Eocene.
Type LOCAlity. - Passy (France). 


\section{DESCRIPTION}

Endocarp bilaterally symmetrical, unilocular, elliptical, lenticular in transverse section; length 6.7-7.2 mm, width c. $4.4 \mathrm{~mm}$, thickness $c .4 .4 \mathrm{~mm}$. Outer part of the endocarp with a reticulate pattern of rounded and thin ridges with a channel on the median apical part of its surface corresponding to the trace left by the outer vasculature at the boundary between endocarp and mesocarp; 4-5 irregular longitudinal ridges and some inter-ridges, enclosing 25-29 polygonal areoles per face with few or no freely ending ridgelets (Fig. 2A, C); a keel surrounds the fruit in the plane of symmetry with one part thicker containing a vascular bundle embedded in the endocarp wall (Fig. 2B). Endocarp possessing a small pair of pores, positioned eccentrically and subapically on the apical endocarp (Fig. 2F); endocarp wall 0.15-0.21 mm thick (excluding ridges, 0.34-0.44 mm thick including ridges, Fig. 2G). Cell walls of the endocarp not preserved. Inner endocarp surface densely covered with regularly spaced and sessile rounded papillae, 0.011-0.019 (avg. $0.016 \mathrm{~mm}$ ) in diameter (Fig. 2H, I).

\section{REMARKS}

This species is represented by only two lignitic endocarps.

\section{SYSTEMATIC AFFINITY}

Iodes passiciensis, sp. nov. is unique in having the following combination of characters: $25-29$ areoles with no freely ending ridgelets, small pores and rounded ridges. This species differs from $I$. reidae Del Rio, Thomas \& De Franceschi in having a pattern of reticulation more developed and a smaller size (both not overlapping). Iodes passiciensis, sp. nov. differs from I. tubulifera Del Rio, Thomas \& De Franceschi in having rounded ridges and a smaller size. The horn-like protrusions are also more obvious in I. tubulifera and protrude sub-apically whereas we have pores in this new species. This species is similar to $I$. rivecourtensis Del Rio, Thomas \& De Franceschi in having rounded ridges, small pores and a reticulation pattern developed without free ending ridgelets. However, I. passiciensis, sp. nov. is smaller, with more areoles, and with a smaller endocarp wall and ridges. This species differs from $I$. sinuosa Del Rio, Thomas \& De Franceschi in having distinctly rounded ridges (despite the absence of cell wall preservation) and a more strongly developed reticulate pattern, but is close in other aspects. Iodes parva Del Rio, Thomas \& De Franceschi is close to this species but is smaller, with fewer areoles and has horn-like protrusions that clearly protrude out from the endocarp wall. It also differs from Iodes occidentalis S.E. Allen, Stull \& Manchester in lack of free-ending ridges and pores. Iodes multireticulata Reid \& Chandler (Stull et al. 2016) lacks pores and are bigger than those of I. passiciensis, sp. nov. Iodes germanica Knobloch \& Mai is slightly smaller $(4-5 \mathrm{~mm})$ than this new species and apparently lacks pores (Knobloch \& Mai 1986). Iodes bilinica (Ettingshausen) Stull, Adams, Manchester \& Collinson differs by the presence of frequent free-ending ridges. The length and width of I. eocenica Reid \& Chandler (Stull et al. 2016) are almost double those of $I$. passiciensis, sp. nov. Iodes acutiformis Chandler possesses an acute apex (Chandler 1962), unlike I. passiciensis, sp. nov., but seems to be very similar in other characters despite having a more relaxed reticulation pattern. Iodes brownii (Berry) Stull, Adams, Manchester \& Collinson and I. corniculata Reid \& Chandler have a similar number of areoles but are larger in size. The channel on the median apical part of the ridges is also found in the species I. rigida Del Rio \& De Franceschi from Le Quesnoy site. However, the ridge structures are different with $I$. rigida that showing an I-beam-like shape of ridges (almost rectangular). All these considerations allow us to describe a new species from these two specimens, which is close to I. sinuosa and I. parva described from the Rivecourt site.

\section{Iodes reidae}

Del Rio, Thomas \& De Franceschi emend. Del Rio \& De Franceschi

(Fig. 2J-Q)

EMENDED DiAgNosis. - Endocarp elliptical with a reticulate pattern of angular to rounded and thin ridges, delimiting 9-19 polygonal areoles per face, with few or no freely ending ridgelets. Endocarp possessing a symmetrical pair of horn-like protrusions, compressed on the keel, positioned eccentrically and subapically. Endocarp wall 0.25-0.34 mm thick (excluding ridges, 0.8-1.1 mm including ridges). Length of endocarp: $9.2-10.9 \mathrm{~mm}$, width: 6.7-7.6 mm.

Stratigraphy. - Late Paleocene.

Additional stratigraphy. - Early Eocene.

Type Locality. - Rivecourt (Oise, France).

Additional locality. - Passy (Oise, France).

SPECIMENS. - MNHN.F.44737.

LATIN CORRECTION OF THE SPECIES NAME. - The suffix -ae replace the suffix -ii in order to be more in accordance with the authors ffirst etymology (this species is in memory of Eleanor M. Reid, Del Rio et al. 2019a).

\section{DESCRIPTION (PASSY SPECIMEN)}

Endocarp bilaterally symmetrical, unilocular, single-seeded, elliptical, laterally compressed in the plane of symmetry, lenticular in transverse section; length $10.9 \mathrm{~mm}$, width $7.1 \mathrm{~mm}$. Outer part of the endocarp with a reticulate pattern of angular to rounded and thin ridges with four longitudinal ridges and two inter-ridges, delimiting 19 polygonal areoles per face (Fig. 2O), with few or no freely ending ridgelets (Fig. 2J, L); a keel surrounding the endocarp in the plane of symmetry with one part thicker, containing a vascular bundle embedded in the endocarp wall (Fig. 2K, Q). Presence of a symmetrical pair of horn-like protrusions compressed on the keel, positioned eccentrically and subapically on the apical endocarp faces, each with a central pit (Fig. 2L); Endocarp wall 0.28-0.34 mm thick (excluding ridges, $0.83-1.1 \mathrm{~mm}$ including ridges, Fig. $2 \mathrm{P}$ ). Cell walls and inner endocarp surface decayed. 

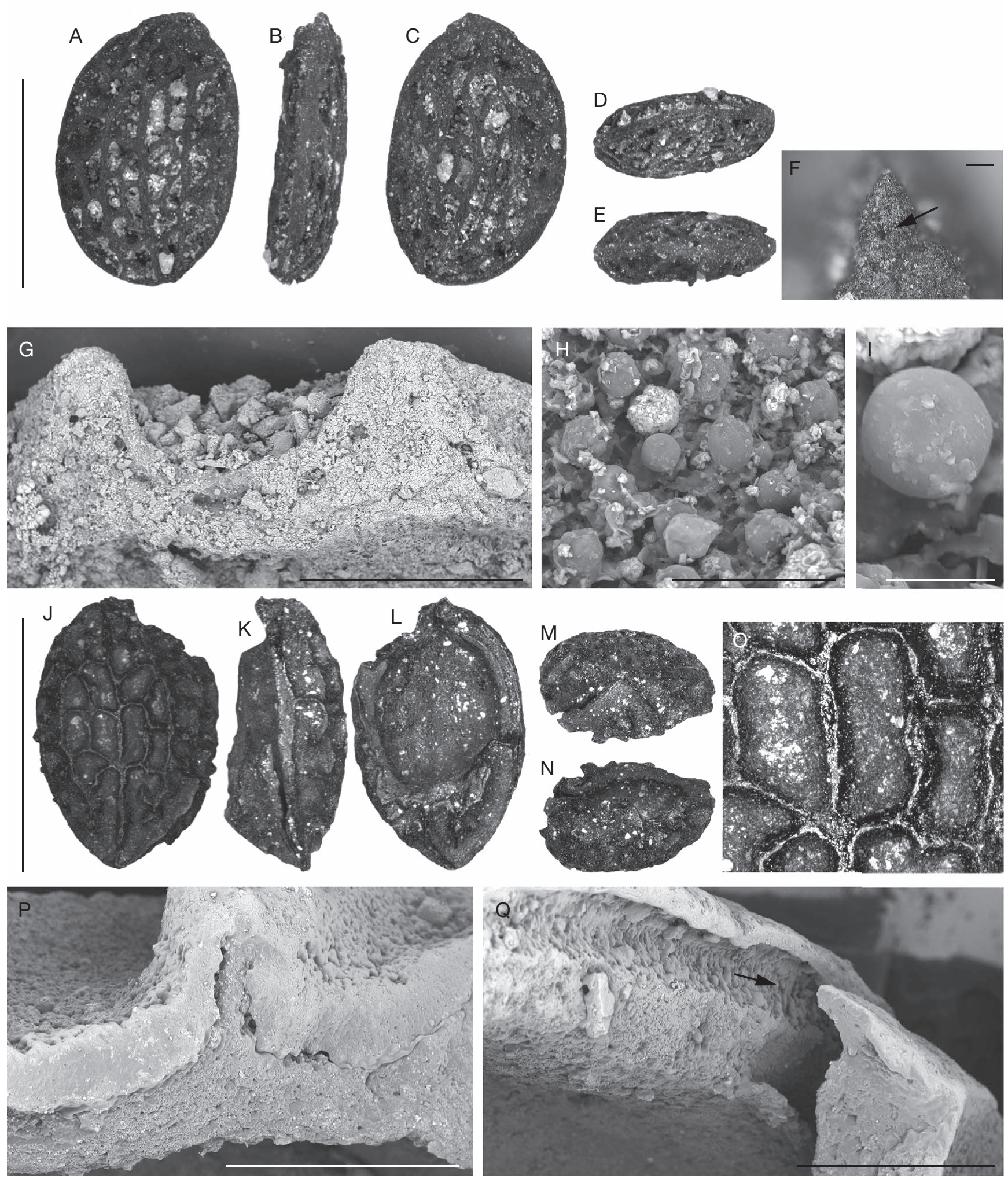

FIG. 2. - A-I, lodes passiciensis Del Rio \& De Franceschi, sp. nov. (MNHN.F.44736): A, lateral view of an endocarp showing the reticulum pattern of rounded and thin ridges; B, dorsal view showing the keel, surrounding the endocarp; C, lateral view of second face of the endocarp; D, basal view; E, apical view; F, magnification showing the pores abraded; G, SEM view of wall and ridges in transversal section; H. SEM view of rounded papillae; I, same with magnification. J-Q, lodes reidae Del Rio, Thomas \& De Franceschi (MNHN.F.44737): J, lateral view of endocarp showing the reticulum pattern of rounded ridges; K, dorsal view showing the keel, surrounding the endocarp; $\mathbf{L}$, lateral view of second face of endocarp; $\mathbf{M}$, basal view; $\mathbf{N}$, apical view; $\mathbf{O}$, magnification showing the areoles from the reticulation of ridges; P, SEM view of wall and ridges in transversal section; Q, SEM view of the trace left by the vascular bundle embedded in the endocarp wall. Scale bar: A-E, 5 mm; O-Q, 1 mm; J-N, 10 mm; G, $500 \mu \mathrm{m} ; \mathrm{F}, 100 \mu \mathrm{m} ; \mathrm{H}, 50 \mu \mathrm{m} ; \mathrm{I}, 10 \mu \mathrm{m}$. 

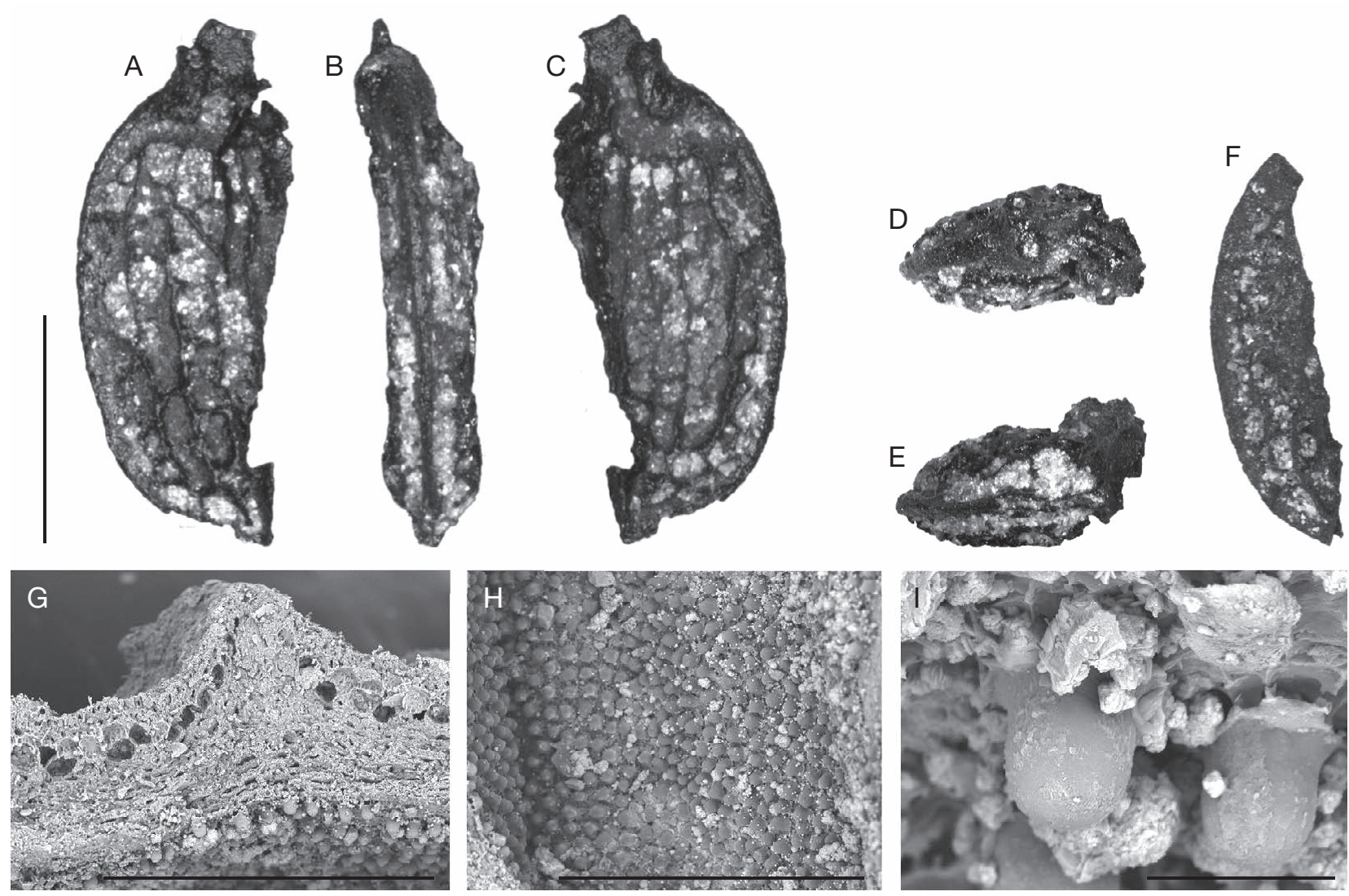

FIG. 3. - A-E, lodes tubulifera Del Rio, Thomas \& De Franceschi (MNHN.F.44738): A, lateral view of an endocarp showing the reticulum pattern of sharp ridges; B, dorsal view showing the keel; C, lateral view of second face of the endocarp; D, apical view showing the small pair of horns (arrows); E, basal view. F-I, MNHN.F.44740; F, lateral view of the endocarp showing the reticulum pattern of sharp ridges; G, SEM view of the endocarp wall units and ridges in transversal section; H, SEM view of tubular papillae; I, same with magnification. Scale bars: A-F, 5 mm; G-H, $500 \mu \mathrm{m}$; I, $30 \mu \mathrm{m}$.

\section{SYSTEMATIC AFFINITY}

This single specimen corresponds in almost all characters to the species Iodes reidae from the Rivecourt site. The ratio of ridge thickness/wall thickness is characteristic of $I$. reidae: a thin endocarp wall with much thicker/higher ridges. Furthermore, the reticulation pattern and the shape of the horn-like protrusions are very similar. The diagnosis of $I$. reidae was emended to encompass the size and areole number of this new species which are very close too. The anatomical characters are not preserved in this specimen.

\section{Iodes tubulifera Del Rio, Thomas \& De Franceschi emend. Del Rio \& De Franceschi}

$$
\text { (Fig. 3) }
$$

EMENDED DIAGNOSIS. - Endocarp elliptical with a reticulate pattern of sharp and thin ridges, delimiting at least 21 polygonal areoles per face, with few or no freely ending ridgelets. Endocarp possessing a symmetrical pair of horn-like protrusions prominent from the keel, positioned eccentrically and subapically. Endocarp wall about $0.2 \mathrm{~mm}$ thick (excluding ridges, about $0.3 \mathrm{~mm}$ including ridges). Inner endocarp surface densely covered with regularly spaced, minute and tubular papillae. Length of the endocarp 8.8-11.2 $\mathrm{mm}$.

STratigraphy. - Late Paleocene.

AdDitional Stratigraphy. - Early Eocene.
TyPe LOCALITY. - Rivecourt (Oise, France).

Additional locality. - Passy (France).

SPECIMENS. - MNHN.F.44738, MNHN.F.44740.

DESCRIPTION (PASSY SPECIMENS).

Endocarp bilaterally symmetrical, unilocular, single-seeded, elliptical, laterally compressed in the plane of symmetry; length 8.8$11.2 \mathrm{~mm}$, width unknown (estimated about 6-7 mm), thickness $1.9 \mathrm{~mm}$. Outer part of the endocarp with a reticulate pattern of sharp and thin ridges, with at least five irregular longitudinal ridges, delimiting at least 23 polygonal areoles per face with few or no freely ending ridgelets (Fig. 3A, C); a keel surrounds the fruit in the plane of symmetry, with the thicker margin containing a vascular bundle embedded in the endocarp wall and the other part thin (Fig. 3B). Endocarp possessing a symmetrical pair of horn-like protrusions prominent from the keel, positioned eccentrically and subapically on the apical endocarp faces, each with a central pit (Fig. 3A, C, D); Endocarp wall 0.2-0.23 mm thick excluding ridges, (0.3-0.33 mm including ridges, Fig. $3 \mathrm{G})$. Wall composed of four units of one or several successive cell rows, the outermost corresponding to an apical sclerotic row, cells difficult to distinguish, sometimes absent by erosion on the areoles, which shows the isodiametric unistratified cell row, cells 0.034-0.053 $\mathrm{mm}$ diameter. The basal sclerotic row forming the 

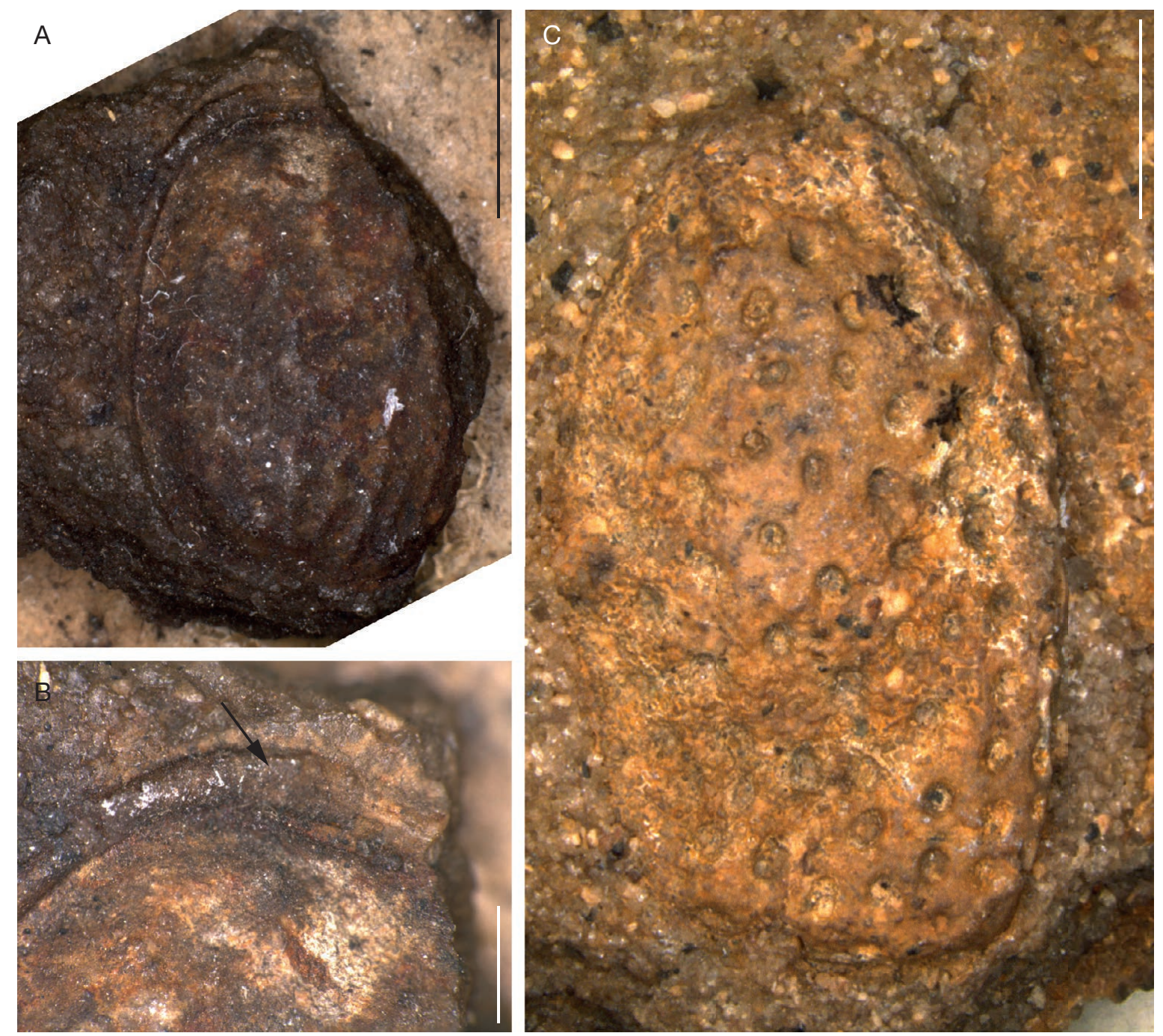

FIG. 4. - A, B, lodes sp. (MNHN.F.8100): A, lateral view of the endocast; B, vascular bundle embedded on the endocarp wall (arrow); C, Palaeophytocrene sp. (MNHN.F.8061), lateral view. Scale bars: A-C, $5 \mathrm{~mm} ; \mathrm{B}, 1 \mathrm{~mm}$.

major part of the endocarp wall thickness is composed of 6-8 sclerotized and periclinal cell rows $0.010-0.013 \mathrm{~mm}$ high, 0.030 $0.041 \mathrm{~mm}$ wide. Inner endocarp surface densely covered with regularly spaced, minute and tubular papillae (cell expansion of the locule epiderma layer); papillae diameter 0.018-0.020 mm, about 290 papillae per $0.25 \mathrm{~mm}^{2}$ (Fig. $3 \mathrm{H}, \mathrm{I}$ ).

\section{SYSTEMATIC AFFINITY}

These two specimens correspond in almost all characters to the specimens of Iodes tubulifera from Rivecourt site. In particular, the presence of characteristic tubular and sparse papillae is strong evidence for this affinity. Here, the density is c. 290 papillae per $0.25 \mathrm{~mm}^{2}$ whereas the density of $I$. tubulifera specimens from Rivecourt is $c .270$ papillae per $0.25 \mathrm{~mm}^{2}$. We think that differences of only 20 papillae per $0.25 \mathrm{~mm}^{2}$ could be due to taphonomic processes or natural range of variation for this species. The sharp ridges and the size of the specimen here support this species assignment. In fact, the sharp ridges are very similar in shape and only slightly higher in the new specimens presented here. The endocarp wall is also very similar in all aspects. The size of the specimens presented here brackets the values of the specimen from Rivecourt. Therefore, we have sufficient justification to attribute these specimens to I. tubulifera.

GRÈS DE BELLEU SITE

\section{Family ICACINACEAE Miers Genus Iodes Blume}

\section{Iodes $\mathrm{sp}$.}

(Fig. 4A, B)

LOCALITY. — Grès de Belleu.

STRATIGRAPHY. - Cuisian.

SPECIMEN. - MNHN.F.8100.

\section{DESCRIPTION}

Endocarp elliptical, abraded in the upper right part, singleseeded with one locule and a lateral vascular bundle embedded 
TABLE 1. - Stratigraphy of the Paris basin, with carpoflora sites with Icacinaceae family in bold, species from each sites and mammal (MP) and pollen (NP) biochronology. Source: Schmidt-Kittler et al. 1987; Aubry et al. 2005.

\begin{tabular}{|c|c|c|c|c|c|}
\hline Stage & sub-stage & Paris Basin & Species & MP & NP \\
\hline \multirow{8}{*}{ Ypresian } & \multirow{3}{*}{ Cuisian } & $\begin{array}{l}\text { Grès de Belleu, sables de Cuise, argiles de Troënes, Prémontré, } \\
\text { Saint Agnan }\end{array}$ & $\begin{array}{l}\text { lodes sp. } \\
\text { Palaeophytocrene sp. } \\
\text { Icacinicaryites sp. }\end{array}$ & \multirow{4}{*}{$\begin{array}{l}\text { MP8 } \\
- \\
9\end{array}$} & \multirow[b]{3}{*}{ NP12 } \\
\hline & & Sables d'Aizy & & & \\
\hline & & $\begin{array}{l}\text { Tuffeau de Mont Notre Dame, sables de Laon, Formation de } \\
\text { Varengeville }\end{array}$ & & & \\
\hline & \multirow{5}{*}{$\begin{array}{l}\text { Sparnacian } \\
\text { facies }\end{array}$} & $\begin{array}{l}\text { Grès d'Urcel, de Bruyère-la-Comtesse, de Challvoie. } \\
\text { Faluns à cyrènes et à huitres }\end{array}$ & & & \multirow{3}{*}{ NP11 } \\
\hline & & Sables de Sincerny, Argiles de Sarron, Sables de Pourcy & & & \\
\hline & & Sables d'Auteuil: Passy & $\begin{array}{l}\text { lodes passiciensis, sp. nov. } \\
\text { lodes reidae } \\
\text { lodes tubulifera }\end{array}$ & & \\
\hline & & \multicolumn{2}{|l|}{ Argiles à lignites du Soissonais et plastiques de Vaugirard } & & \multirow[t]{2}{*}{ NP10 } \\
\hline & & $\begin{array}{l}\text { Calcaires de Clairoix, Mortemer, Cap d'Ally, Marnes de Sincerny, } \\
\text { Dormans, Chenais (p.p.), Cendrier de Paris, Lamorlaye, } \\
\text { Montgiroux, Conglomérat de Meudon, Le Quesnoy }\end{array}$ & $\begin{array}{l}\text { lodes rigida } \\
\text { lodes acuta } \\
\text { lodes parva } \\
\text { Icacinathium tainiaphorum }\end{array}$ & MP7 & \\
\hline \multirow[t]{2}{*}{ Thanetian } & & Sables de Bracheux, Rivecourt & $\begin{array}{l}\text { lodes sinuosa } \\
\text { lodes parva } \\
\text { lodes reidae } \\
\text { lodes tubulifera } \\
\text { lodes rivecourtensis }\end{array}$ & & \multirow[t]{2}{*}{ NP9 } \\
\hline & & Travertins de Sézanne & & MP6 & \\
\hline
\end{tabular}

in the endocarp wall (Fig. 4B). Base rounded, symmetrical. Endocarp reticulate, forming some polygonal areoles and with five longitudinal ridges (Fig. 4A). Anatomical detail unknown. Length $13.2 \mathrm{~mm}$, width $8.7 \mathrm{~mm}$.

\section{REMARKS AND AFFINITIES}

A single specimen was found. Despite the lack of anatomical detail, especially regarding the presence and morphology of papillae, we assign this specimen to the extant genus Iodes, because it possesses a vascular bundle embedded in the endocarp wall and a reticulate pattern in ornamentation. These two characters are only found in the extant genera Iodes and Icacina (and the fossil genus Iodicarpa Manchester but with faint reticulation). However, Icacina species are generally much larger and more globular in shape. The lack of anatomical characters hinders the recognition of a new species. The length and width of the specimen is close to Iodes eocenica (Reid \& Chandler 1933; Cleal et al. 2001) but narrower and could be close to Iodes multireticulata; without sufficient anatomical preservation for comparison with other fossil species, it remains impossible to attribute it to a particular species.

\section{Genus Palaeophytocrene Reid \& Chandler}

\section{Palaeophytocrene sp.}

(Fig. 4C)

LOCALITY. - Grès de Belleu.

STRATIGRAPHY. - Cuisian.
SPECIMEN. - MNHN.F.8061.

\section{DESCRIPTION}

Endocarp locule cast oval in lateral view. Apex rounded, apparently symmetrical, base flattened, symmetrical. Outer part of locule cast pitted, apparently not ridged (specimen abraded). Pits circular to elongate, about 0.58-0.86 (avg. $0.72 \mathrm{~mm}$ ) in width, 0.82-1.02 (avg. 0.94) $\mathrm{mm}$ in length, randomly arranged, with 8-10 pits in length, 5-6 pits in width (about 60 pits by face). Pits associated with conical to parallel-sided protuberances. Locule cast length $21 \mathrm{~mm}$, width $12 \mathrm{~mm}$.

\section{REMARKS AND AFFINITIES}

This occurrence is represented by a single specimen. The outer part of the locule cast with pits and tubercles, parallelsided or conical shape (revealed by a silicone mould of the pits), allows the attribution of this specimen to Palaeophytocrene. Thus, this specimen represents the first occurrence of Palaeophytocrene from the Paris Basin. In term of size, this specimen seems to be close to the London Clay species (Reid \& Chandler 1933) Palaeophytocrene ambigua Reid \& Chandler and Palaeophytocrene foveolata Reid \& Chandler, but $P$. ambigua endocarps has fewer and smaller pits and P. foveolata has smaller pits as well. P. vancouverensis Rankin \& Stockey (Rankin et al. 2008), from Vancouver island, corresponds in pit diameter and pit number (in length and in width). However, the poor anatomical preservation of MNHN.F.8061. does not allow us to assign this fossil to any species. 

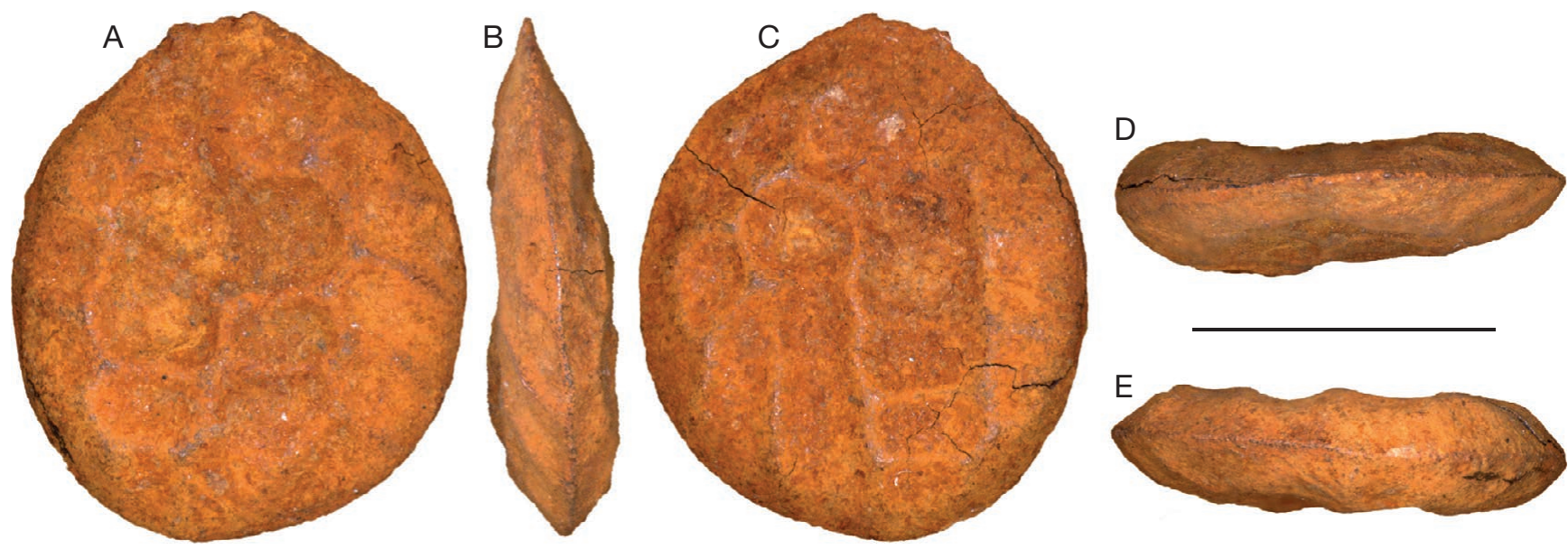

FIG. 5. - Icacinicaryites sp. (MNHN.F.44741): A, lateral view; B, dorsal view showing the keel; C, other lateral view; D, apical view; E, basal view. Scale bar: 5 mm.

\section{PRÉMONTRÉ SITE}

Family ICACINACEAE

Genus Icacinicaryites Pigg, Manchester \& DeVore

\section{Icacinicaryites sp.}

(Fig. 5)

StratigrapHy. - Cuisian.

Locality. — Prémontré (France).

SPECIMEN. - MNHN.F.44741.

\section{DESCRIPTION}

Fossil bilaterally symmetrical, elliptical; unilocular and singleseeded, length $8.8 \mathrm{~mm}$, width $7.6 \mathrm{~mm}$. Apex slightly asymmetrical, base rounded, symmetrical. Outer part of locule cast with reticulate pattern of rounded ridges; face of locule cast with 3-4 longitudinal ridges enclosing 6-9 polygonal areoles on each lateral face with few or no freely ending ridgelets; a keel surrounds the locule cast in the plane of symmetry (?); cellular details unknown.

\section{REMARKS}

Only one specimen represents the Icacinaceae in this outcrop. We found no thicker part on the keel which suggests that this specimen is a locule cast rather than the complete endocarp. In the absence of apparent anatomical preservation, we choose to include this specimen in the genus Icacinicaryites without species name. This specimen could be close to Iodes multireticulata sensu Reid \& Chandler (1933) but with fewer areoles. It may correspond to Iodes rigida from Le Quesnoy site, but the reticulation pattern does not match. This specimen seems to have a unique morphology despite the lack of anatomical characters.

\section{OVERVIEW OF ICACINACEAE}

FROM THE PARIS BASIN

Here we review all the accepted occurrences of the Icacinaceae from the Paris Basin (Table 1). In addition to fruits from Passy, Belleu and Prémontré studied here, we include the fruits from Rivecourt (Paleocene; Del Rio et al. 2019a) and Le Quesnoy (early Eocene, Del Rio et al. 2019b) and a flower from Le Quesnoy (Del Rio et al. 2017).

Occurrences of triporate and echinate pollen belonging to the Compositoipollenites genus (with Icacinaceous affinity) have been described for the Paris Basin. Compositoipollenites medius Krutzch \& Vanhoorne, 1977, Compositoipollenites minimus Krutzch \& Vanhoorne, 1977 and Compositoipollenites rhizophorus burghasungensis (Murriger \& Pflug, 1952) Thomson \& Pflug, 1949 were found in the Le Quesnoy site and the Paleocene of Guitrancourt (Cavagnetto 2000, Kedves 1970). Moreover, Compositoipollenites minimus was also found in Nointel (early Eocene, Oise; see Kedves 1970) and Compositoipollenites rhizophorus (R. Potonié, 1934) R. Potonié, 1960 at Paris Austerlitz (late Eocene, Paris; see Kedves 1970). However, some author consider that we have not enough data from other families that also have echinate pollen to confidentially conclude about these affinities (Manchester et al. 2015). We decided to follow the same caution and we do not include them in our analysis. No leaves or woods remains have been attributed to Icacinaceae in the Paris Basin.

\section{GENERAL DISCUSSION}

ICACINACEAE DIVERSITY OF THE PARIS BASIN

The Paris Basin holds an Icacinaceae diversity comparable to other well-documented sites in Europe and North America (Reid \& Chandler 1933; Knobloch \& Mai 1986; Manchester 1994; Collinson et al. 2012). Within the Paris Basin, 12 species of Icacinaceae have been documented, nine of which are only found in the Paris Basin; additionally, there are three icacinaceous fossil taxa without specific assignment (Table 1). These species represent only one extant genus (Iodes) and three extinct genera (Palaeophytocrene, Icacinicaryites, Icacinanthium). In comparison, 21 species in seven genera were recorded in the London Clay flora (early Eocene; Reid \& Chandler 1933), ten species in five genera in the Messel biota (middle Eocene; 
Collinson et al. 2012) and eight species in five genera in the Clarno Formation (middle Eocene; Scott 1954; Manchester 1994). However, our sites range from the Thanetian to Ypresian, which is a greater stratigraphic range than the other sites cited here, making the direct comparisons difficult.

Within Iodes, nine species have been described, in four different time intervals: five in Rivecourt (Thanetian), three in Le Quesnoy (early Ypresian), three in Passy (middle Ypresian) and one in Grès de Belleu (end of Ypresian). Species from Rivecourt have been found in Le Quesnoy (Iodes parva) and Passy (Iodes reidae and Iodes tubulifera), revealing a floristic continuity in the Paris Basin during the Paleocene and early Eocene. In particular, this is the first time that the same species has been recognized before and after the Paleocene-Eocene boundary in all the fossil record for Icacinaceae. Some genera were in common through the Paleocene-Eocene, e.g., Iodes, Palaeophytocrene, but not at the species level, making only indirect floral links. The Iodes sp. specimen described from the Grès de Belleu is the biggest of the Paris Basin and comparable to the London Clay specimens. However, the other sites of the Paris Basin with Icacinaceae remains do not have the same preservation as the Grès de Belleu presumably due to different taphonomic process, making size comparison difficult.

The Palaeophytocrene specimen from Grès de Belleu is comparable to the species from the London Clay and from North America, but differs in some aspects. This specimen attests the presence of this genus in the Paris Basin during the Cuisian.

Finally, Icacinanthium tainiaphorum, a flower embedded in amber from Le Quesnoy (Del Rio et al. 2017), shows an unexpected diversity for the Icacinaceae family. Indeed, this flower represent a new extinct genus not directly related to what we found in the fruit fossil record. This flower, at the base of the clade IV (Stull et al. 2015), adds a phylogenetic diversity apparently not documented by the known fruits remains.

Extant Iodes is a genus of tropical to sub-tropical climbers, and Palaeophytocrene is an extinct genus with a probable affinity with the tribe Phytocreneae (Sleumer 1942), also composed of tropical to sub-tropical climbers. Moreover, Icacinanthium is close to tropical and sub-tropical climbing clade (clade IV, Stull et al. 2015). Thus, all Icacinaceae fossil remains through the Paris Basin sites seem to be related to climber species. Studies about the link between diversity of the forest and representation in the litter shows that litter represents much more the local than the regional vegetation (Burnham 1989; Burnham et al. 1992). Climbers are often abundant in the river banks and channels; thus, the representation of only Icacinaceae climbers could be a bias. On this point, the ancient diversity of Icacinaceae is likely underestimated. Indeed, it is common to find in the same area many Icacinaceae climber and trees genera with many species in extant Icacinaceae diversity (Sleumer 1971; Villiers 1973; Peng \& Howard 2008). For Iodes, as it is the most represented genus in the Paris Basin, we have in comparisons seven species in Malaysia (Sleumer 1971), five species in Cameroon (Villiers 1973) and four species in Madagascar (Perrier De La Bâthie 1952) in modern diversity. Our fossils found in Rivecourt, Le Quesnoy and Passy are close to the extant diversity in these noted areas for this genus.
BIOGEOGRAPHIC INSIGHTS

Several fossils from the Paris Basin have biogeographic connections with extant and extinct species. Palaeophytocrene sp. specimen from the Grès de Belleu as well as Iodes sp. may show affinities with other European and North American paleofloras, underscoring the close connection between these two areas during the Eocene (Manchester 1994; Stull et al. 2016). The source of dispersion, whether from North America to Europe or from Europe to North America, still represents a controversial subject in mammalian palaeontology (Godinot \& de Broin 2003; Smith et al. 2006; Beard 2008). The presence of diverse Iodes species with horn-like protrusions in the Paleocene Rivecourt site, morphologically closely resembling to the Eocene Iodes brownii from the Wyoming, United States, suggests a dispersion during the Eocene from Europe to North America for Iodes species. However, the Palaeophytocrene species indicates a potential dispersion during the Eocene from North America to Europe, the older Palaeophytocrene occurrence being in North America during the Paleocene (Stull et al. 2012). This suggests that Eocene migration occurred in both directions.

The Eocene flora of Europe is often compared to the extant Indo-Malaysian vegetation. This modern flora is considered as a relic of the ancient boreotropical widespread flora (Reid \& Chandler 1933; Wolfe 1975). Among the fossil Icacinaceae from the Paris Basin, there is some evidence for this biogeographic pattern. Only extant Iodes from eastern Asia possesses clear horn-like protrusions or pores at the apex (see Del Rio et al. 2019b), which are also evident in Iodes parva from Le Quesnoy and Iodes passiciensis, sp. nov., Iodes reidae and Iodes tubulifera from Passy. However, Iodes rigida and Iodes acuta from Le Quesnoy do not have horn-like protrusions and are apparently closer to the extant Iodes from Africa. In addition, the reticulation patterns of all Iodes from the Paris Basin are closer to some modern African species, for example, Iodes klaineana Pierre. The fossils seem to have a combination of characters now found separately in both areas. In addition, Icacinanthium tainiaphorum Del Rio \& De Franceschi is close to the clade IV (Stull et al. 2015) which contains African (Pyrenacantha Hook \& Desmostachys Planch ex Miers) and Asian (Hosiea Hemsl. \& E.H. Wilson, Sarcostigma Wight \& Arn., Miquelia Blume, Phytocrene Wall., Ryticaryum Becc. \& Natsiatum Buch.Ham. ex Arn) genera. This flower seems to be more related to Hosiea and Natsiatum, which are endemic to the Asian area (Del Rio et al. 2017), but the phylogenetic position of both genera allows the flower to be considered only at the base of all Clade IV genera. As discussed above, Palaeophytocrene belongs to the Phytocreneae tribe, which is found in Asia and Africa. Thus, the floristic affinities between the Paleogene European and modern floras are not as clear for Icacinaceae as proposed in literature. There is uncertainty between African and Asian affinities in all cases. This modern floral pattern could be a consequence of floral regression and disjunction during the Oligocene, as Icacinaceae being extinct in Europe. Thus, these comparisons are made among ancient widespread floras and extant probably refugial floras, which does not directly address the center of origin for the Icacinaceae family. 


\section{Acknowledgements}

We would like to thank Valentin Seizilles de Mazancourt for the help on Latin names. We are grateful to Steven R. Manchester and to another anonymous referee for their fruitful suggestions, which notably improved the manuscript. This work was supported by a grant from Agence Nationale de la Recherche under the LabEx ANR-10-LABX-0003-BCDiv, in the program "Investissements d'avenir" n_ ANR-11IDEX-0004-02 and by the CR2P (UMR 7207) and use a digital microscope financed by the national infrastructure e-RECOLNAT (ANR-11-INBS-0004) and Région Île-deFrance through the Domaine d'intérêt majeur (DIM) "Heritage and ancient materials.

\section{REFERENCES}

ADNET S. \& CAPPETTA H. 2008. - New fossil triakid sharks from the early Eocene of Prémontré, France, and comments on fossil record of the family. Acta Palaeontologica Polonica 53 (3): 433 448. https://doi.org/10.4202/app.2008.0306

Allen S. E., STUll G. W. \& MANCHESTER S. R. 2015. — Icacinaceae from the Eocene of western North America. American Journal of Botany 102 (5): 725-744. https://doi.org/10.3732/ajb.1400550

Aubry M.-P., Thiry M., Dupuis C. \& Berggren W. A. 2005. The Sparnacian deposits of the Paris Basin: A lithostratigraphic classification. Stratigraphy 2 (1): 65-100.

Augé M. 2003. - La faune de Lacertilia (Reptilia, Squamata) de l'Éocène inférieur de Prémontré (Bassin de Paris, France). Geodiversitas 25 (3): 539-574.

Augé M. \& Smith R. 2002. - Nouveaux Lacertidae (Reptilia, Squamata) de l'Eocène inférieur européen. Belgian Journal of Zoology 132 (1): 3-15.

Augé M., Duffaud S., Lapparent de Broin F. de, Rage J. C., VASSE D. 1997. - Les amphibiens et les reptiles de Prémontré (Cuisien, Bassin parisien) : une herpétofaune de référence pour l'Eocène inférieur. Géologie de la France 1: 23-33.

BEARD K. C. 2008. - The oldest North American primate and mammalian biogeography during the Paleocene-Eocene Thermal Maximum. Proceedings of the National Academy of Sciences 105 (10): 3815-3818. https://doi.org/10.1073/pnas.0710180105

Blanc-Louvel C. 1985a. - Paléoflore du gisement éocène de Prémontré dans l'Aisne : étude de deux fruits. Acte du 110e Congrès des Sociétés savantes: 149-161.

BlanC-Louvel C. 1985b. - Paléoflore du gisement éocène de Prémontré dans l'Aisne : Vitaceae. Acte du $110^{e}$ Congrès des Sociétés savantes, fasc. 2: 37-48.

BURNHAM R. J. 1989. — Relationships between standing vegetation and leaf litter in a paratropical forest: implications for paleobotany. Review of Palaeobotany and Palynology 58 (1): 5-32. https://doi. org/10.1016/0034-6667(89)90054-7

Burnham R. J., Wing S. L. \& PARKer G. G. 1992. — The reflection of deciduous forest communities in leaf litter: implications for autochthonous litter assemblages from the fossil record. Paleobiology 18 (1): 30-49. https://doi.org/10.1017/S0094837300012203

CAPPETTA H. 1992. - Carcharhiniformes nouveaux (Chondrichthyes, Neoselachii) de l'Yprésien du Bassin de Paris. Geobios 25 (5): 639-646. https://doi.org/10.1016/0016-6995(92)80103-K

Cavagnetto C. G. 2000. — La palynoflore d'un gisement d'ambre de l'Eocène basal du Bassin Parisien (Le Quesnoy, France). Palaeontographica Abteilung B 255 (4-6): 147-171.

CHANDLER M. E. J. 1962. - The Lower Tertiary floras of Southern England. II. Flora of the Pipe-Clay Series of Dorset (Lower Bagshot). British Museum of Natural History, London, $176 \mathrm{p}$.

Cleal C. J., Thomas B. A., Batten D. J., Collinson M. E.
2001. - Mesozoic and Tertiary paleobotany of Great Britain Peterborough, Geological Conservation Review Series 22, 335 p.

Collinson M. E., Manchester S. R. \& Wilde V. 2012. — Fossil fruit and seeds of the Middle Eocene Messel biota, Germany. Abhandlungen der Senckenberg Gesellschaft für Naturforschung 570: 1-251.

COMBES P. 1907. — Contribution à l'étude de la flore éocène. Sur un bois fossile nouveau appartenant à l'étage sparnacien (Aulacoxylon sparnacense). Bulletin de la Société géologique de France, sér. $4,7: 28,29$.

De Franceschi D. \& De Plö̈g G. 2003. — Origine de l'ambre des faciès sparnaciens (Éocène inférieur) du Bassin de Paris : le bois de l'arbre producteur. Geodiversitas 25 (4): 633-647.

De Franceschi D., Dejax J. \& De Plö̈g G. 2000. — Extraction du pollen inclus dans l'ambre [Sparnacien du Quesnoy (Oise), bassin de Paris] : vers une nouvelle spécialité de la paléopalynologie. Comptes-Rendus de l'Académie des Sciences - Series IIA - Earth and Planetary Science 330 (3): 227-233. https://doi. org/10.1016/S1251-8050(00)00126-9

Dégremont E., Duchaussois F., Hautefeuille F., Laurain M., LOUIS P. \& TETU R. 1985. - Paléontologie : découverte d'un gisement du Cuisien tardif à Prémontré. Bulletin d'Information des Géologues du Bassin de Paris 22 (2): 11-18.

Del Rio C., Haevermans T. \& De Franceschi D. 2017. — First record of an Icacinaceae Miers fossil flower from Le Quesnoy (Ypresian, France) amber. Scientific Report 7 (1): 11099. https:// doi.org/10.1038/s41598-017-11536-y

Del Rio C., Thomas R. \& De Franceschi D. 2019a. - Fruits of Icacinaceae Miers from the Paleocene of the Paris Basin (Oise, France). Earth and Environmental Science Transactions of the Royal Society of Edinburgh 108 (4): 459-469. https://doi.org/10.1017/ S1755691018000221

Del Rio C., Stull G. W. \& De Franceschi D. 2019b. - New species of Iodes fruits (Icacinaceae) from the early Eocene Le Quesnoy locality, Oise, France. Review of Palaeobotany and Palynology. 262: 60-71. https://doi.org/10.1016/j.revpalbo.2018.12.005

ESCARGUEL G. E. 1999. - Les rongeurs de l'Éocène inférieur et moyen d'Europe occidentale. Systematique, phylogénie, biochronologie et paléobiogéographie des niveaux-repères MP 7 à MP 14. Palaeovertebrata 28 (2-4): 89-351.

FAiron-Demaret M. \& SMith T. 2002. - Fruits and seeds from the Tienen Formation at Dormaal, Palaeocene-Eocene transition in eastern Belgium. Review of Palaeobotany and Palynology. 122 (1-2): 47-62. https://doi.org/10.1016/S0034-6667(02)00103-3

Fritel P. H. 1908. - Révision des Myricacées fossiles du grès de Belleu. Bulletin de la Société géologique de France 4 (8): 274-280.

FRITEL P. H. 1924. - Suite et additions à la révision de la flore cuisienne des grès de Belleu. Bulletin de la Société géologique de France 4 (24): 150-175.

FURON R. \& SOYER R. 1947. - Catalogue des fossiles tertiaires $d u$ Bassin de Paris. Vol. 6. P. Lechevalier, Paris, 240 p.

Godinot M. \& DE BROIN F. DE L. 2003. —-Arguments for a mammalian and reptilian dispersal from Asia to Europe during the Paleocene-Eocene boundary interval. Deinsea 10 (1): 255-276.

Godinot M., Russel D. E. \& LouIs P. 1992. — Oldest known Nannopithex (Primates, Omomyiformes) from the early Eocene of France. Folia Primatologica 58 (1): 32-40. https://doi. org/10.1159/000156604

JacQUes F. M. B. \& De Franceschi D. 2005. - Endocarps of Menispermaceae from Le Quesnoy outcrop (Sparnacian facies, Lower Eocene, Paris Basin). Review of Palaeobotany and Palynology 135 (1-2): 61-70. https://doi.org/10.1016/j.revpalbo.2005.02.005

KEDVES M. 1970. —Études palynologiques des couches du Tertiaire inférieur de la région Parisienne.V. Pollen triporés, subtriporés et intratriporés. Pollen Spores 12 (1): 83-97.

Knobloch E. \& Mai D. H. 1986. - Monographie der Fruchte und Samen in der Kreide von Mitteleuropa. Vydal Ustredni ustav geologicky 47: 1-219. 
Koeniger J. C. 1982. - Un site à bois et empreintes dans les grès de Belleu (Cuisien) du Tardenois. Congrès national des Sociétés savantes 1: 97-107.

MANCHESTER S. R. 1994. - Fruits and seeds of the Middle Eocene nut beds flora, Clarno Formation, Oregon. Palaeontolographica Americana 58: 1-205 p. https://www.biodiversitylibrary.org/ page/ 28068042

MAnchester S. R., Grímsson F. \& Zetter R. 2015. —Assessing the fossil record of Asterids in the context of our current phylogenetic framework 1. Annals of the Missouri Botanical Garden 100 (4): 329-363. https://doi.org/10.3417/2014033

MÉGNIEN C. 1980. - Synthèse géologique du Bassin de Paris (No. 101-103). Édition du bureau de recherches géologiques et minières.

Nel A., De Plöeg G., DejaX J., Dutheil D., De Franceschi D., Gheerbrant E., Godinot M., Hervet S., Menier J.-J., Augé M., Bignot G., Cavagnetto C., Duffaud S., Gaudant J., Hua S., Jpssang A., de Lapparent de Broin F., Pozzi J.-P., Paicheler J.-C., Beuchet F. \& Rage J.-C. 1999. — Un gisement sparnacien exceptionnel à plantes, arthropodes et vertébrés (Éocène basal, MP7) : Le Quesnoy (Oise, France). Comptes-Rendus de l'Académie des Sciences - Series IIA - Earth and Planetary Science 329: 65-72. https://doi.org/10.1016/S1251-8050(99)80229-8

Peng H. \& Howard R. A. 2008. - Icacinaceae, in Zhengy W. \& Raven P. H. (ed.), Flora of China. Science Press, Beijing - Missouri Botanical Garden, St. Louis: 505-513.

Perrier de la BÂTHIE H. H. 1952. - Icacinacées (Icacinaceae), in Humbert H. (ed.) Flore de Madagascar et des Comores. Vol. 119. Firmin-Didot et Cie, Paris: 1-45. https://biodiversitylibrary.org/ page/9313999

PigG K. B., Manchester S. R. \& Devore M. L. 2008. - Fruits of Icacinaceae (Tribe Iodeae) from the Late Paleocene of western North America. American Journal of Botany 95 (7): 824-832. https://doi.org/10.3732/ajb.2007340

Pomerol C., Boureaux M., Bournerias M., Dorigny A., Solau J.-L. \& VANTINEL M. 1984. - Notice explicative de la feuille Soissons à 1/50 000. Bureau de Recherches géologiques et minières, Paris: 5-46.

RANKIN B. D., STOCKey R. A. \& BeARD G. 2008. - Fruits of Icacinaceae from the Eocene Appian Way Locality of Vancouver Island, British Columbia. International Journal of Plant Sciences 169 (2): 305-314. https://doi.org/10.1086/523876

RASBAND W. S. 2016. — “ImageJ Website." https://imagej.nih.gov/ij/

Reid E. M. \& Chandler M. E. J. 1933. - The London Clay Flora. The British Museum (Natural History), London, 561 p. https:// doi.org/10.5962/bhl.title.110147

Schmidt-Kittler N., Brunet M., Godinot M., Franzen J. L., HoOKer J. J. \& Legendre S. 1987. — European reference levels and correlation tables. Münchner, Geowissenschaftliche, Abhandlungen A 10: 15-31.

SсотT R. A. 1954. - Fossil fruits and seeds from the Eocene Clarno Formation of Oregon. Palaeontographica Abteilung B 96: 66-97.
Sleumer H. 1942. - Icacinaceae, in Engler A. (ed.), Die Natürlichen Pflanzenfamilien. Engelmann, Leipzig, 20b: 322-396.

Sleumer H. 1971. - Icacinaceae, in VAN STEenis C. G. G. J. (ed.), Flora Malesiana. Wolters-Noordhoff, Leiden, 7 (1): 1-87.

SMith R. 2001. — Les pantolestides (Mammalia, Pantolesta) de l'Éocene inférieur de Prémontré (Aisne, France). Palaeovertebrata 30 (1-2): 11-35.

Smith T., Rose K. D. \& Gingerich P. D. 2006. — Rapid AsiaEurope-North America geographic dispersal of earliest Eocene primate Teilhardina during the Paleocene-Eocene thermal maximum. Proceedings of the National Academy of Sciences 103 (30): 11223-11227. https://doi.org/10.1073/pnas.0511296103

Smith T., Quesnel F., De Plöeg G., De Franceschi D., Metais G., De Bast E., Sole F., Folie A., Boura A., Claude J., Dupuis C., Gagnaison C., IakOvleva A., Martin J., Maubert F., Prieur J., Roche E., Storme J.-Y., Thomas R., Tong H., Yans J. \& BUFFETAUT E. 2014. - First Clarkforkian equivalent land mam$\mathrm{mal}$ age in the latest Paleocene basal sparnacian facies of Europe: fauna, flora, paleoenvironment and (bio)stratigraphy. PLoS ONE 9 (1): 1-20. https://doi.org/10.1371/journal.pone.0086229

SUDRE J. \& ERFURT J. 1996. - Les artiodactyles du gisement yprésien terminal de Prémontré (Aisne, France). Palaeovertebrata $25(2-4): 391-414$.

SOYER R. 1953. - Carte géologique à 1/50000, $N^{\circ} 183$ - Notice. Bureau de Recherches géologiques et minières, Paris, 8 p.

Stull G. W., Moore B. R. \& Manchester S. R. 2011. - Fruits of Icacinaceae from the Eocene of southeastern North America and their biogeographic implications. International Journal of Plant Sciences 172 (7): 935-947. https://doi.org/10.1086/660877

Stull G. W., Herrera F., Manchester S. R., Jaramillo C. Tiffney B. H. 2012. - Fruits of an "Old World" tribe (Phytocreneae; Icacinaceae) from the Paleogene of North and South America. Systematic Botany 37 (3): 784-794. https://doi. org/10.1600/036364412X648724

Stull G. W., Duno de Stefano R., Soltis D. E., Soltis P. S. 2015. - Resolving basal lamiid phylogeny and the circumscription of Icacinaceae with a plastome-scale data set. American Journal of Botany 102 (11): 1794-1813. https://doi.org/10.3732/ajb.1500298

Stull G. W., AdAms N. F., MANCHester S. R., SyKes D. \& COLLINSON M. E. 2016. - Revision of Icacinaceae from the Early Eocene London Clay flora based on X-ray micro-CT. Botany 94 (9): 713-745. https://doi.org/10.1139/cjb-2016-0063

VILLIERS J.-F. 1973. - Icacinaceae, in AUBRÉVILLE A. \& LEROY J.-F. (ed.), Flore du Cameroun. Muséum national d'Histoire naturelle, Paris, France: 3-100.

Watelet A. 1866. - Description des plantes fossiles du Bassin de Paris. J-B. Baillière et Fils, Paris, 256 p.

WolfE J. A. 1975. - Some aspects of plant geography of the Northern Hemisphere during the late Cretaceous and Tertiary. Annals of the Missouri Botanical Garden 62 (2): 264-279. https:// doi.org/10.2307/2395198 https://doi.org/10.2307/2395198 